\title{
THE ICONOGRAPHY AND FUNCTION OF Winged GODS IN EgYPT DURING THE GRACO-RoMAN PERIOD
}

\author{
Sara El-Sayed Kitat \\ Lecturer, Guidance Department \\ Faculty of Tourism and Hotels, Alexandria University
}

\begin{abstract}
This research analyzes the iconography and function of winged gods in Graco-Roman Egypt. "Wind deities" appeared as winged scarabs or winged four-headed rams. Osiris was also represented in the shape of a winged scarab, a winged sun disc, or a winged mummy.Harpokrateswas figured with wings on magical stelae and gems. The winged solar disc of Horus Behdety decorates the façade of the Egyptian temples. Moreover, Seth appeared in the form of a winged god in the temple of Hibis. Bes is depictedwith wings on amulets and statuettes. The winged sphinxof Tutu was used to ward off demons. God Chnoubisis also depicted as a winged goat-headed scarab in the Egyptian art. The Greek god Eros appeared as a winged boy on the walls of Stagni tomb in KomEl-Shokafa. Hypnos, the Greek god of sleep, is depicted as a winged youth on Ariadne sarcophagus.

The wings of the Egyptian gods spring from their arms or sides unlike the wings of Greek gods which spring only from their backs. The shape of the Egyptian winged gods was employed in protective and magical purposes. On the other hand, Greek gods inspired their winged iconography from their mythic roles.
\end{abstract}

\section{Introduction}

In ancient Egypt, winged deities, whether male or female, played a crucial protective function. Their guardianship reached the livings and even the deceased. Extraordinary shapes of deities were used to protect people from personal manifestations or divine emissaries. These deities were usually depicted with wings andappeared as composite beings which have numerous heads and different symbols of power ${ }^{(1)}$. For example, there is a magical papyrus from Heliopolis from the fourth-third century B.C that depicts a winged ithyphallic deity with nine animal heads surmounted by rams' horns, snakes, and knives. He holds scepters, serpent wands, and is surrounded by torches. This exotic deity is portrayed trampling on images of dangerous animals ${ }^{(2)}$ (fig.1). A similar ithyphallic figure with two pairs of wings is engraved on the first register of the Metterinch stela that dates back to the Thirtieth Dynasty. This figure was described to be one of the forms of god Re and was called "the Great Magician" (3).

In a Demotic spell to recall the deceased, the medium child is described to be protected by an amulet that consists of four white, four green, four blue, and four red threads woven into a band. This amulet was soaked into blood of a hoopoe and attached to a winged scarab wrapped in fine linen ${ }^{(4)}$.

The usage of winged deities in Egypt continued as long as the late Roman period. For instance, there is a golden ring that represents a winged deity, who is probably god Horus. This example dates back to the third century A.D. Its setting consists of a circular 
hematite amulet in a good condition. It depicts a four-winged god with four-arms. The deity is portrayed as a standing youth facing an empty cartouche formed by an ouroboros. Anuraeus appears at each side of the neck. His arms hold upright four tall staves, apparently four wAs-scepters. Horus wears here an apron with an amulet on his chest. The elaborate headdress is made up of three parts; the vulture cap of the goddess Mut, a trapezoid, and a trident-like ornament, perhaps the hemhem crown. The vulture headdress was used to symbolize the protective abilities of the mother-goddess Mut to Horus the

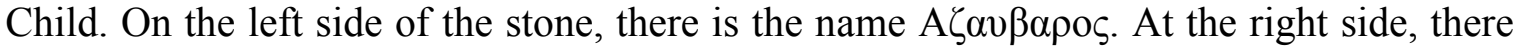
is a column of meaningless signs, among them a star; two or three can be read as Greek letters ${ }^{(5)}$ (fig. 2).

In Græco-Roman Egypt, the winged gods could be classified into two types; the Egyptian winged gods, and the Greek ones.

\section{Egyptian Winged Gods}

Wind Deities. By the Græco-Roman period, the wind began to be personified on the walls of sarcophagi, tombs and temples. They were either represented in an animal form or as a human figure holding the symbols of the wind ${ }^{(6)}$.

In the Theban system, wind deities were represented in the form of a ram-headed scarab beetle or a ram with four heads ${ }^{(7)}$. The ram bears the two curved horns of Amun topped by two horizontal horns and the ostrich feather of god Shu. Four shapes of wind deities were depicted to represent the northern, southern, eastern, and western winds. They were represented facing each other. North is opposite the south and east is opposite the west. The body of each figure is different. Both the northern and southern winds were usually represented with the body of a ram. The eastern wind was depicted in the form of a scarab in the majority of the scenes. As for the western wind, it appeared usually in the shape of a falcon. Two wings were added to the iconography of wind deities ${ }^{(8)}$. Their depiction gives examples of the variation in which the ancient Egyptians provide composite shapes of their deities ${ }^{(9)}$.

An example of the animal-shaped wind deities is found in the temple of Deir el Madinah. The eastern wind is depicted in the form of a ram headed scarab with two wings. Beside this composite figure, the northern wind is portrayed as a four-winged ram with four heads ${ }^{(10)}$ (fig.3.a). Moreover, the southern wind is depicted in the form of a fourwinged ram. As for the western wind, it is represented as a ram headed falcon with four wings ${ }^{(11)}$ (fig.3.b).

In some rare cases, wind deities were depicted in the form of small winged genii. Taking the shape of god Heh, god of infinity and air, only the wings explain that these figures are the wind divinities. The four figures were either male or female and thus could be compared with the goddesses of the four cardinal points that are depicted in the temple of Deir El Hagar in Dakhla oasis ${ }^{(12)}$.

In the temple of Denderah, there is a scene representing the four wind deities as winged figures with outstretched arms. All of them are portrayed holding the ankh sign in one hand and a mast in the other one ${ }^{(13)}$. The north wind is depicted as a ram headed man and crowned with two horizontal horns and four straight feathers of god Onuris (fig.4.a). Concerning the south wind, it is depicted in the shape of an ape headed man crowned with the solar disc and the cobra ${ }^{(14)}$ (fig.4.b). The east wind is figured as a serpent headed 
human crowned with two horns and four feathers of god Onuris (fig.4.c). Finally, the west wind appears as a four serpent headed figure wearing the feather of god Shu over his head $^{(15)}$ (fig.4.d).

Osiris. The Egyptian god Osiris was represented in the shape of a winged scarab and a winged sun disc in certain cases. According to R. L. Shonkwiler, these representations were driven from Osiris' obvious connection with the heavenly bodies and his identification with the sun god $\mathrm{Re}^{(16)}$.

In the Osirian chapel of Denderah temple, there is a representation of winged discs and winged scarab beetles alternating with vultures which are identified with Nekhbet and Wadjet. According to the accompanying text, the winged scarab is here identified with Osiris (fig.5). On the ceiling of this chapel, the texts named the winged disk as Osiris identified with god $\operatorname{Re}$ (the sun), the moon, and the constellation of Orion ${ }^{(17)}$.

Being the god of the otherworld, many coffins and stelae appeared being decorated with winged scarab and discs, symbols of god Osiris. The winged sun disc was usually depicted at the top of the coffins and stelae. Concerning the winged scarab, it was respectively found surrounding the chests of the women's mummy masks and coffins ${ }^{(18)}$. For example, there is a shroud that is preserved now in Boston Museum of Fine Arts. This piece represents a mummiform body enface wearing a broad collar that is protected from both sides with two winged falcons, wedjat-eyes, and the crook and flail, which are symbols of the Osirian kingship in the underworld. In addition, the portrait of the deceased is flanked with two winged cobras, named by the hieroglyphic symbols on their heads as Isis and Nephthys. Surrounding the head of the mummy, there is a figure of a winged scarab beetle. The scarab symbolizes the sun god, who could travel as a winged sun disc across the sky. It evokes also Osiris, from the otherworld from whose head a scarab appeared when he lay on his funerary bier at his cult center $\operatorname{Abydos}^{(19)}$ (fig.6).

In addition to the winged sun disc, Osiris appeared also in the form a winged mummiform figure. This representation is found engraved on a magical stone made of obsidian and preserved in the British Museum (no. 56525). Osiris is depicted as a standing mummy wrapped in a network of bandages. He is crowned with the sun disk and vulture's head at each side of face. Two pairs of wings are attached to shoulders of the deity. A small figure is engraved beneath Osiris. It is probably Harpokrates who is represented sitting with knees drawn up, back to the mummy ${ }^{(20)}$ (fig.7).

Horus. Horus Behdety. The iconography of Horus Behdet as a sun disc with two falcon wings became popular by the Ptolemaic period. His image decorated the walls of the Egyptian temples and the gates of their sanctuaries ${ }^{(21)}$. The myth of Horus of Edfu appeared as early as the Ramesside period. It represents the fight of Horus Behdety who could defeat the evil powers embodied in Seth and his companions; namely the crocodiles, and the hippopotami. At the end of this legend, Horus as a winged solar disc could achieve victory over Seth ${ }^{(22)}$.

The myth says that during the reign of Rahorakhty, a great revolt broke out in Lower Nubia and was led by the evil god Seth. Re dispatched Horus in the form of a winged sun disc who could defeat them. Rewarding his efforts, Re gave Horus the title Horus of Edfu. However, the enemies did not give up as they took the shape of crocodiles and hippopotami and attacked the bark of Re himself. Therefore, Horus took again the shape of the winged sun disc and set himself in the prow of the ship. He defeated his enemies 
and their leader Seth by killing and blinding them. Commemorating his victory, god Thoth ordered to place the image of the winged sun disc of Horus Behedety in every temple in Egypt ${ }^{(23)}$ (fig.8).

The myth of Horus Behdety is pictorially represented on the walls of Edfu temple. It is inscribed on the second register of the inner face of the western enclosure wall of Edfu temple. Sixteen scenes running from north to south represent the complete myth of Horus Behdety which is described in the text as follows; irapynt(y) hr n3 g3y.wt $n$ ntr.wntr.wtnb(.w) nwtA.wysxmw.w=snmit(t) Hr BHd.t(y) pw "As for the Winged Disk which is upon the shrines of all the gods and goddesses of the Two Lands (and upon) their chapels likewise, it is Horus the Behdetite" (24).

Besides his mythic role, the representation of Horus Behdety as a winged sun disc might have been driven from his function as a solar deity ${ }^{(25)}$. Horus of Edfu was identified with Rahorakhty and was described to be the son or even the soul (bA) of the sun god ${ }^{(26)}$. Horus Behdety was also considered being the moon or Re at night ${ }^{(27)}$. Therefore, Horus of Edfu was described as "Re-Behdetite, Lord of the Sky"(28). According to the previous texts, Horus of Behdet was described as a winged sun disc and thus identified with the supreme solar god (Re/Khepri) ${ }^{(29)}$. On the other hand, some scholars interpret the wings of the sun disc to be representative of the sky ${ }^{(30)}$.

Being venerated as a god of war, the two wings of the solar disc of Horus referred to the god's ability in protecting the two lands of Egypt ${ }^{(31)}$. During the Græco-Roman period, the epithet "lord of Mesen" is quite often associated with one side or wing of Horus Behdety to associate him with Lower Egypt ${ }^{(32)}$. On the north or the western side of this epithet, another title appears which is "Foremost of the Lower Egyptian Shrine Row" either replacing the title "BHd.ty" at the beginning of the inscription or following it at some point. On the opposite wing, the title "BHd.ty" appears being followed by the epithet "Foremost of the Upper Egyptian Shrine Row" (33). In the temple of Edfu, a hymn is inscribed in the hall outside the sanctuary of the high seeds. Part of the hymn describes Horus Behdet as the one; "who comes out of the horizon in the two temples of the South and North" (34).

In addition to the previous depiction, Horus Behdety was also depicted in Edfu in the form of a beetle (api) with two wings ${ }^{(35)}$ (fig.9). Unlike the winged sun disc, the beetle is here provided with more insect-like wings which were never shown attached to the solar sun disc ${ }^{(36)}$. In the naos of Nectanebo I at Edfu, Horus the Behdetite is entitled as apywrxntykArnb "Great Winged Beetle, Foremost of every Shrine" (37). The word Apy is written as a winged scarab beetle ${ }^{\prime}{ }_{H}^{*}$ which was identified with Horus Behdety during the Græco-Roman period ${ }^{(38)}$.

The depiction of Horus Behdety as a winged beetle is rarely found before the Ptolemaic period. In the tomb of Tutankhamun (1336-1327 B.C.), items and pictorials show winged beetles which could be interpreted as Behdet ${ }^{(39)}$. In the temple Edfu, a scarab beetle with two falcon wings is depicted on the ceiling of the naos of Nectanebo. Two winged scarabs are depicted pushing the solar sun disc with their front legs and grasping the Sn sign with their hind legs ${ }^{(40)}$. According to the accompanying text, both winged scarabs were named Behdet ${ }^{(41)}$. Part of the inscription says; "As for the Winged Beetle which is on the shrines of all gods and goddesses of Upper and Lower Egypt, he is Horus of Behdet" (42). 
Harpokrates. In addition to Horus Behdet, another shape of Horus appeared in the winged form which is Hours the Child. The winged iconography of Harpokarets appeared mainly on the magical objects such as; magical gems and stelae. For example, the obverse of an oval gem of gray beryl represents the pantheos type of god Horus. This piece which belongs to the magical gems of the British Museum represents Harpokarets as a nude standing youth with a beardless face and rays projecting from his head. Two wings are attached to the shoulders and thighs of Horus who is apparently holding an animal in one hand and resting the other on his hip. Moreover, a harsh-featured face with prominent nose is depicted in profile at the left side of Horus ${ }^{(43)}$.

Greek magical words are engraved from the four sides of god Horus. These words were commonly found in the magical papyri, amulets, and gems. The word Abrasax $\alpha \beta \rho \alpha \sigma \alpha \xi$ is engraved over the figure of Horus. It was the name of a good in the system of the gnostic religious teacher in Alexandria, namely Basilides. This word was regarded being a magical spell that was commonly found inscribed on late Hellenistic amulets and talismans. On the left side of this piece, another magical word is inscribed which is $\alpha \kappa \rho \alpha \mu \mu \alpha \chi \alpha \mu \alpha \rho \varepsilon$. This word associated the figure of Harpokrates on many magical gems. The word (S)esengenbarpharanges $\sigma \varepsilon \sigma \varepsilon v \gamma \varepsilon v \beta \alpha \rho \varphi \alpha \rho \alpha v \gamma \eta \varsigma$ is found on the right side. The second part of this name apparently means "the son (bar) of Tartarus" which was a Greek city in Palestine known as Gehenna in the valley son of Hinnom. IaoAbrasax $\alpha \beta \lambda \alpha v \alpha \theta \alpha v \alpha \lambda \beta \alpha$ is inscribed beneath the figure of Harpokrates ${ }^{(44)}$ (fig. 10).

Seth.Seth was also represented as a winged figure ${ }^{(45)}$. The deity appears here in anthropomorphic shape with a human body and an animal head. He is depicted with two wings and killing snakes ${ }^{(46)}$. This remarkable iconography could be found on a bas relief in the temple of Hibis in Kharga Oasis. The god is depicted as a falcon headed god and crowned with the Pesheshet crown. Seth is killing the snake facing him with his lance ${ }^{(47)}$ (fig.11).

The winged iconography of Seth is attested since the Pharaonic Period. For instance, there is a rounded-topped stela that depicts Seth as a winged deity. This piece, which dates back to the Nineteenth dynasty, represents Seth in the form of a bull-headed winged god. Seth who is named "bull of Ombos", is depicted standing in his barque and spearing Apophis snake. The piece is now preserved in Ny Carlsberg Glyptotek (ÆIN. 726) in Copenhagen ${ }^{(48)}$.

A third example is a Ramessidescarab from Tell el-Farah and represents Seth as a winged, barefooted god standing at the prow of a boat. In the frontal part of the barque, there is a resting bird. Seth wears here Egyptian nemes headdress and holds a long spear in his hand. According to the accompanying inscription, this figure is identified as Seth who spears Apophis serpent from the barque of Amun- $\mathrm{Re}^{(49)}$. The shape of Seth's tasseled kilt reveals the Canaanite influence. Therefore, the depicted figure could be Seth assimilated with god Baal, namely Baal-Seth. In other words, the depicted figure represents a combination between the Egyptian Seth who defeats the Apophis snake and the Canaanite Baal who conquers the sea serpent litanu/Leviathan. The two deities were regarded as serpent conquerors. Apophis serpent was a symbol of darkness and dangerous powers and thelitanu serpentwas a symbol of danger and stormy sea ${ }^{(50)}$.

The Egyptian god Seth was identified with certain foreign deities such as; Baal, and Resheph in his winged representation. An exampleof this identification is a fragment of a 
sandstone stela from the temple of Ramses II (1279-1212 B.C.) in Matmar. The stela represents a headless winged figure of a deity which is depicted standing in profile and spearing a snake, apparently Apophis snake with his spear. This god is depicted wearing the short shendjyt kilt with two long tassels attached to the frontal part of the kilt. The tassels attached to the Egyptian kilt are of an Asiatic origin. The depicted figure is identified by Cornelius as the winged Baal-Seth ${ }^{(51)}$. However, Grande rather believes that the depicted figure belongs to god Resheph identified with Seth ${ }^{(52)}$.

The cult of the Canaanite god Reshep was introduced to Egypt by the reign of Amemhotep II (1425-1401 B.C.). In the ancient Egyptian art, Resheph was depicted wearing an Asiatic garb, a high tiara, and a gazelle head ornament. Being originally a war god, Resheph appeared his weapons among them the spear and shield ${ }^{(53)}$. According to Grande, the depicted wings were the only artistic feature that distinguishes this deity from many other Phoenician deities worshiped in Egypt. This might led us to assume that the winged iconography of Resheph had an Egyptian origin. The wings were added to the iconography of Resheph because of his frightening and protective character as a war god that he obtained in Egypt. In other words, wings were added to the iconography of this deity to represent his supernatural powers. It is worth to mention that one of the epithets of Resheph was "Resheph-sprm" meaning "Reshaph of the wings" (54).

The winged iconography of Reshep was identified with the Egyptian god Seth which took the same representation as a winged animal headed deity and spearing Apohissnake ${ }^{(55)}$. The crown of Resheph was the evidence of the identification between Resheph and Seth as the latter was worshipped as god of deserts where gazelles could be found $^{(56)}$.

An example of the winged Reshep could be found on a fiancé plaque preserved now in the Royal Art and History Museums in Brussels. This piece, which dates back to the period between Nineteenth-Twentieth Dyansties, depicts Resheph standing in profile with his chest en face. His arms as well as his wings are widely opened. Two crossed bracelets decorate the chest of the god. Resheph wears a high conical tiara over his head and his forehead bears a decorative ornament, apparently a gazelle head. Furthermore, the deity is represented wearing a short kilt and killing the snake before him with a spear. Traces of inscription could be read as follows; sAanxhAnb meaning "protection life behind the

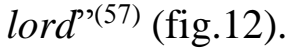

Bes. By the end of the New Kingdom, Bes began to be represented as a winged deity. This depiction spread widely as early as the Ptolemaic period (fig.13). Many Phoenician amulets bear the new iconography of this deity. The wings of Bes, which are sometimes doubled to four wings, spring either from his arms or from his sides. This representation spread as early as the Late Period. Heads of gazelle suspend from the wings of Bes in some cases ${ }^{(58)}$. A bone plaque in Anatolia and a limestone figurine at Byblos represent Bes in the winged shape. These objects date back to the Middle Bronze Age which is contemporary with Egypt's Middle Kingdom. The depiction of the winged shape of Bes on Phoenician amulets might confirm the foreign origin of the deity. The attire of Bes especially his kilt and his wings are apparently an eastern inspiration in general and a Phoenician effect in particular ${ }^{(59)}$.

The winged iconography of Bes is usually found on magical objects such as; gems and magical stelae. It was known that Bes functioned as a protective god and was especially 
connected with the solar cult. Thus, Bes became a divine guardian at night. Therefore, his shape was used to decorate the beds, headrests, mirrors, boxes, equipments of toilets, chairs, and everything that could be found in bedrooms ${ }^{(60)}$. In addition, the winged figure of Bes appeared on many stelae and had the same function of the cippi of Horus ${ }^{(61)}$.

The winged depiction of Bes was also used to protect the deceased in the underworld from any evil powers. For instance, the coffin of Panakht represents the judgment of the deceased whose head is surrounded by the winged shape of Bes. This coffin was discovered in Kharga Oasis, specifically in Tomb N5, the northern necropolis of El-Deir and dates back to the first half of the first century A.D ${ }^{(62)}$. This iconography of Bes is painted upon the shoulders of the deceased. Despite of the bad state of the coffin, the figure of god Bes is seen depicted en face with protruding tongue and holding a snake in one hand and a key in the other one. The key is associated with the cult of god Shu who was depicted holding the solar key in his hand. His two wings appear beneath the elbow of the deity. Traces of colors are still visible in the face and shoulders (fig. 14). Similar representation of Bes is found in tomb N5 in the necropolis of El-Deir where Bes is depicted with two wings of three rows of feathers ${ }^{(63)}$.

Bes regarded to be the divine protector against all sorts of devils, the guardian of the underworld gates, and the protector of the deceased's body. Therefore, Bes was represented side by side with god Anubis in the funerary art. Both of them accompanied the deceased and introduced him to the otherworld. A Hellenized fusion of Bes appeared being assimilated with the winged Greek god Hermes ${ }^{(64)}$.

Tutu. During the Graeco-Roman period, there was a protective deity named Tutu which was described was to be the son of goddess Neith. Tutu combines attributes of a sphinx and a griffin (fig. 18). He has a human head, the body of a lion, the wings of a bird, and a tail of a snake. His most common title was "the one who keeps enemies at a distance". His monstrous power and iconography were used to ward off demons and hostile representations of other deities ${ }^{(65)}$.

Tutu was sometimes depicted as a sphinx with outstretched wings. This manifestation could be connected in a way or another with the verb 3. be written with this sign ${ }^{(66)}$. Thus, the winged sphinx of Tutu god was used to reveal his speed when he travelled to rescue men ${ }^{(67)}$. One of the titles of Tutu was XAxnmtt which means "swift to pace". By this way, the wings here were used to indicate this aspect of Tutu who could answer the prayers of his worshippers immediately ${ }^{(68)}$.

O. Kaper published three Roman stelae depicting the winged sphinx of Tutu in profile ${ }^{(69)}$. One of them is preserved now in the Egyptian Museum (no. 37538). It is a rectangular limestone stela that represents the figure of Tutu with outstretched wings is high relief. The deity appears as a winged pantheistic sphinx striding towards the left. His heavy curly wig is covered by the nemes headdress and the hemhem crown. The griffin of PetbeNemesesis holding the wheel of fortune is depicted upon the back of Tutu. According to the accompanying text, this stela was dedicated by the high priest of Amun called Kosmaros to god Tutu ${ }^{(70)}$ (fig.15).

Chnoubis. This deity is regarded a composite god of god Khnum assimilated with Amun. He was sometimes depicted as a winged goat-headed scarab. The two horns are colored in green. Two ankh signs suspend from the uraeui surmounting the horns of the deity. This iconography refers to his regenerative powers. The shape of Chnoubis is found on the 
walls of the Egyptian temples, the majority of the coffins, and the Theban and Memphite sarcophagi $^{(71)}$ (fig.16).

\section{Greek and Roman Winged Gods}

Among the various Greek and Roman winged gods, they appeared in Egypt on a limited scale as follows;

Eros. Eros (Roman: Amor, Cupido which means "desire of love") son of goddess Aphrodite and god Ares or even Uranus ${ }^{(72)}$. According to Hesiod's Theogony, Eros is one of the primordial deities, and was regarded to be the child of Chaos and brother of Gaia, Erebus, Nyx (Night), and Tartarus ${ }^{(73)}$.In another myth, Eros was described to be the son of Iris, messenger of the gods, and Zephyrus, the West Wind. In Aristophanes' Birds, Eros emerged from an egg of Erebus and Nyx and appeared "with his glittering golden wings" (74). Socrates and Plato gave Eros then name "Petrotes" which means "Winged Love"(75).

Eros was the god of passion and love between mortals or deities. He was also regarded the divine patron of patriotism or love of the country which unites an army together. $\mathrm{He}$ fell in love with princess Psyche who conceived under the shape of a small winged maiden or a butterfly ${ }^{(76)}$. Eros is variously represented as a beautiful youth or a small boy, usually nude. He can be depicted with or without his wings. His attributes are the bow and arrows or is garlanded of flowers, especially, roses. He pricks deities as well as mortals with his arrows to inflame their hearts with desire. In the case of having of more one figure of Eros in the same scene, these figures were called Erotes ${ }^{(77)}$.

Despite of being god of love, the figure of Eros appeared in funerary buildings. For instance, two shapes of Erotes are painted on the exterior surfaces of the two piers supporting the pediment of Stagni tomb in Kom el-Shokafa. This small tomb dates originally back to the Ptolemaic period was enlarged and refurnished during the Roman times. The two figures of Erotes are depicted as standing winged boys en face ${ }^{(78)}$ (fig. 17).

Another example is a magical gem from the British Museum that depicts Eros seated on ground. He rests his chin on his right hands while his feet are depicted caught in trap. Over the trap, there is an oval shape that might be a representation of rock or a temple. The left hand rests in crook of right elbow. Eros' right wing is here depicted behind the head. Eros bends his back on a small tree behind him. This piece is made of Sardonyx, brown layer over white ${ }^{(79)}$ (fig.18).

Hypnos. Hypnos (or: Sumnos) is the Greek god of sleep. He is the son of night Nyx (Night) and Erebus. He was also the twin brother of death Thantos ${ }^{(80)}$. Hypnos was depicted as a powerful youthful man either nude or wearing a heavily clad. He was also portrayed as a child or bearded aged man in some cases ${ }^{(81)}$. The deity was described as a winged man who can fly through the air in many classical sources such as; Homer's Iliad, Ovid's Metamorphoses, and Pausanias's Description of Greece $^{(82)}$. On his head, there are two wings of a hawk or a night bird. In the Iliad, goddess Hera ordered Hypnos to take the shape hawk. A lizard frequently is depicted beside this god. The winged deity is represented holding a poppy or a horn from which sleep trickled down from those responding ${ }^{(83)}$. 
The wings were added to this mysterious god who was described to live in the dark cave in the underworld, in the land of Cimmerians, or the land of Lemnos ${ }^{(84)}$. Hypnos was portrayed surrounded by his thousand sons, the dreams, lying beside him ${ }^{(85)}$.

In the British Museum, there is a remarkable bronze head for god Hypnos with the two wings of a hawk projecting from the temples. However, the origin of attaching wings to the Greek temples remains a topic of debate ${ }^{(86)}$.

The solemn representation of this deity in Egypt is on the so-called Ariadne sarcophagus. This marble sarcophagus was discovered in Alexandria and dates back to the second century A.D. Among the myth of Ariadne, Hypnos is depicted as a winged youth with poppy stalk and a small horn in his hands. He is depicted standing behind the sleepy Ariadne and caressing her with his right hand ${ }^{(87)}$ (fig.19).

\section{Results}

In Græco-Roman Egypt, adding wings to the manifestations of certain gods had a certain symbolic value. The ancient Egyptian considered the pair of wings an element that endowed his gods with unusual scheme to face his fears of unknown evil powers during his life or even after his death. In other words, wings were used to indicate the protective and supernatural aspect of his deities. Therefore, wings were added to the shapes of the Egyptian gods to represent their abilities in warding off evil spirits and dangers such as; death, unknown powers, deserts, and diseases. Therefore, there is no wonder to find the winged Egyptian gods being involved in the field of magic. Revealing their supernatural abilities, the winged Egyptian deities appeared on magical gems, stelae and magical spells. Osiris and Harpokrates are regarded examples of these deities.

Moreover, wings were exceptionally used to represent certain natural powers especially the wind which seemed to be mysterious and powerful by the ancient Egyptian. Two or even four wings were added to the composite divine representations of the wind in ancient Egypt. This iconography which appeared by the Ptolemaic period was used to reveal the function of these figures as wind deities. The Egyptian artist apparently wanted to represent the supernatural powers of the four winds by depicting them in the form of composite creatures or human figures with one or two pairs of wings.

In addition, the winged depiction of certain Egyptian deities was connected to the solar cult in the Egyptian myth. The winged scarab and the winged sun disc were used to refer to god Osiris and Horus Behdet. The winged iconography of Osiris reveals his identification with the sun god Re. In funerary art, Osiris was also depicted as a winged scarab referring to the sun god, who could travel as a winged sun disc across the sky. It recalls also Osiris, from under whose head a scarab appeared when he lay on his funerary bier at his cult center Abydos. Horus Behdet was also depicted in the form of a solar disc with two wings. Moreover, Horus of Edfu was identified with Rahorakhty and was described to be the son or even the soul (bA) of the sun god in the temple of Edfu. Like god Osiris, Horus Behdety was also depicted as a winged beetle in the temple of Edfu. In addition to Osiris and Horus of Behdet, Chnoubis was also depicted in the form of a ram headed beetle. This composite shape represents the assimilation between two Egyptian deities, namely Khnum and Amun.

Wings could also used to represent the two parts of ancient Egypt and thus connect with the concept of kingship. According to a text in the temple of Edfu, the wings of 
Horus of Edfu were used to refer to Upper and Lower Egypt. This representation reveals the function of Horus Behdet as the god of the two lands ${ }^{(88)}$.

Seth was one of the prominent Egyptian gods who took the shape of a winged deity. This manifestation appeared in the temple of Hibis in Kharga oasis. It apparently indicates the function of Seth as a protective god against the dangers of the desert. Being assimilated with other foreign deities, namely, Baal, and Reshef, the two former deities were identically represented as Seth in his winged iconography. They took the same shape of an animal headed god standing in profile with two wings. The deity is usually represented killing Apophis snake with his spear. This might reflect the supernatural powers of the three deities in warding off the evil spirits.

It is worth to mention that Horus of Behdet and Seth identified with Reshep were venerated as war deities. Both of them took the winged iconography. The ancient Egyptian apparently intended to recall the supernatural powers of his deities to face his enemies in the battles by adding wings to their divine shapes.

In the ancient Egyptian art, the shape of the Egyptian winged gods was various and sometimes sophisticated. The number of the wings was doubled to be two or three wings in certain cases. They could be represented en face or in profile. Seth and his foreign counterparts, namely Baal and Resheph were usually depicted in the form of winged gods in profile. Unlike the Greek artist, the Egyptian one did not restrict himself in drawing two wings. He used his imagination to draw more than two wings. Furthermore, the number of the wings was directly proportional with the danger that is intended to be protected from. In other words, the greater the danger is, the more wings are depicted. Thus, deities with more than two wings appeared in the field of magic in particular.

In addition, the ancient Egyptian added sometimes two wings to certain natural elements, insects, as well as animals to refer to his winged gods. For example, the winged solar disc, the winged scarab, and the winged ram appeared on many pieces of the Egyptian art and architecture to refer to certain deities such as; Osiris, Horus of Behdet, and Chnounbis.

On the other hand, the Greek winged gods appeared in Egypt on a limited scale. Their winged manifestations based on their mythic role. The Greek artist apparently added wings to the small boy Eros to reveal his dreamy aspect as a god of love. Concerning the sleep god Hypnos, he was depicted as winged man caressing the head of the sleeper.

Unlike the Egyptian winged gods, the wings of the Greek gods appeared through simple representations in Græco-Roman Egypt. Despite of showing the details of the feathers, the Greek and Roman artists did not prefer to double the number of the wings and kept their shapesas simple as possible. Eros and Hypnos were the Greek winged deities which appeared in Egypt during that time. The winged shape of Eros appeared in the funerary art, sculpture, as well as magical gems. As for god Hypnos, he was rarely represented in Græco-Roman Egypt. The marble sarcophagus of Ariadne considered being the most prominent example.

It is worth to note that winged deities, whether Egyptian or Greek, were repetitively shown in profane art. Osiris, Horus Behdet, Bes, Eros, and even Hypnos were found depicted on stelae, coffins, and sarcophagi. Revealing the unusual powers of these gods, the artist used the winged figures of such deities to assist the deceased through his journey to the other world. 


\section{Conclusion}

Number of Egyptian and foreign gods appeared in the winged shape in Egypt during the Græco-Roman period. The wings were used to reveal the supernatural powers of the Egyptian deities facing certain mysterious dangers such as; deserts, snake bites, evil spirits, war dangers, and death. They could also be used to embody certain natural powers in the Egyptian environment especially the wind. Wings were added to certain Egyptian deities to recall their abilities in warding off evil spirits or even conquering their enemies in the battles. Numberof Egyptian winged gods were also connected with sun cult and thus with the concept kingship. The Egyptian winged deities were represented with one or two pairs of wings. On the other hand, limited number of foreign deities appeared in Græco-Roman Egypt with only one pair of wing. The artist used here wings to represent their mythic function.

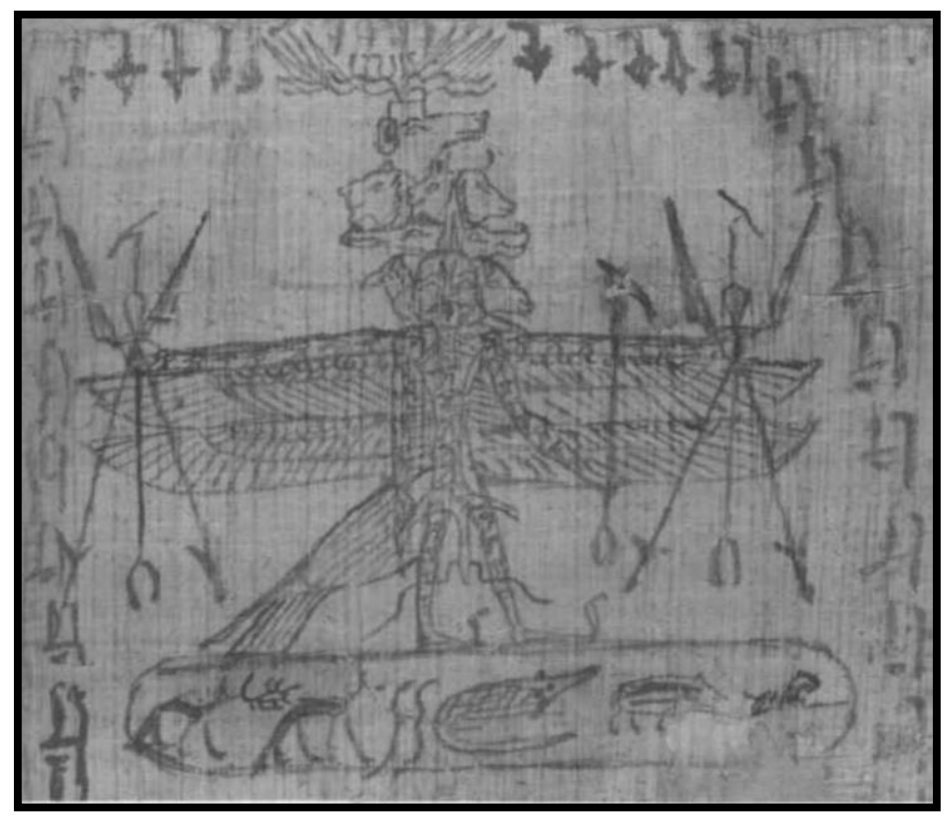

Figure 1 : Figure of a wingedpantheistic deity from amagical papyrus, third-fourth centuries B. C.

After: Pinch, Magic in Ancient Egypt, 37, no. 17

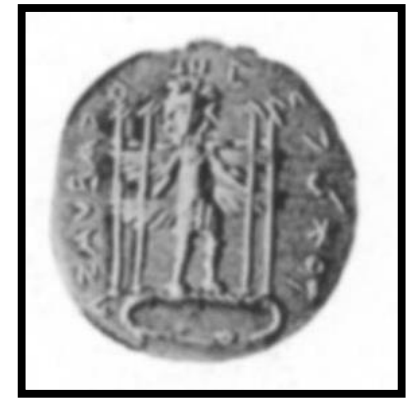

Figure 2: Four winged shape of a deity (probably Horus), third century A.D.

After: Bonner, "Amulets Chiefly in the British Museum", pl. 100, supplement, 17 


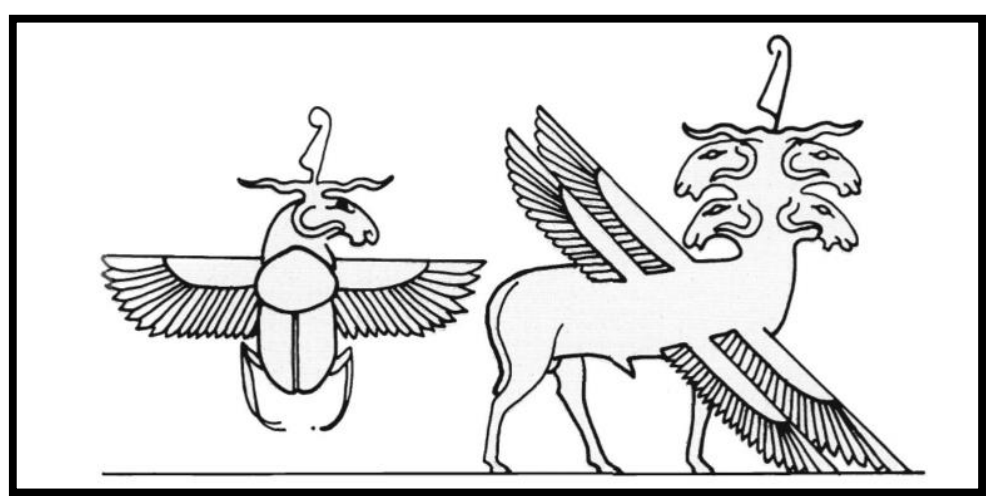

Figure 3: a. god of the eastern wind (left) and god of the northern wind (right), temple of Deir El -Madineh, Ptolemaic Period

After:Wilkinson, The Complete Gods and Goddesses of Ancient Egypt, 29.

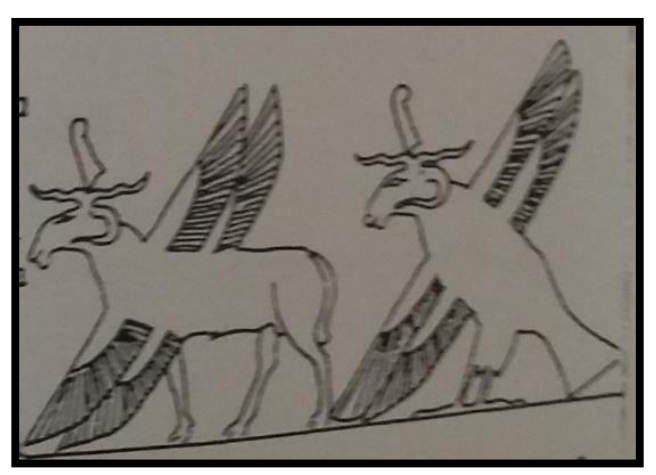

Figure 3: b. god of the southern wind (left) and god of the western wind (right), temple of Deir El -Madineh, Ptolemaic Period

After: El-Kasrawy, The Wind in the Ancient Egyptian Culture, fig. 123b. 


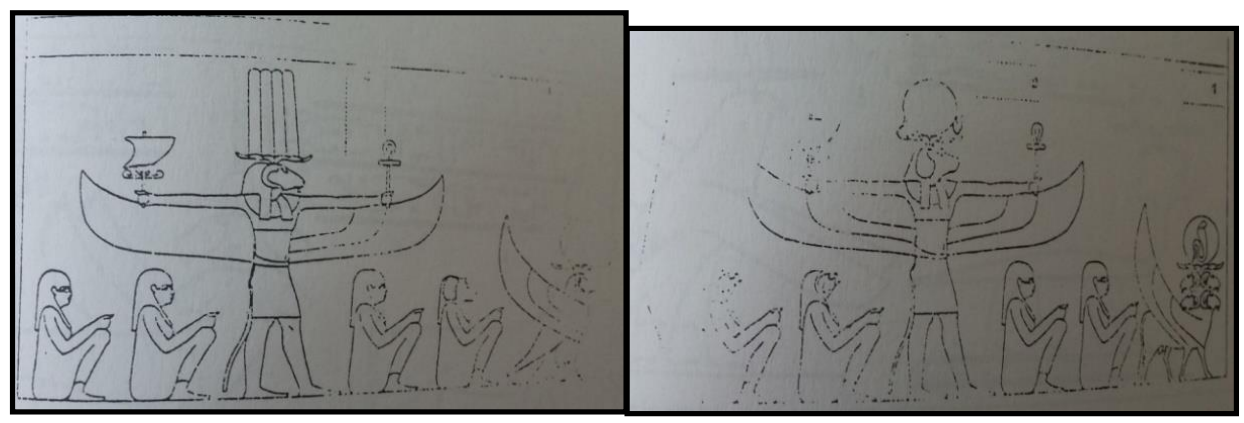

a. God of northern wind $\quad$ b. God of southern wind

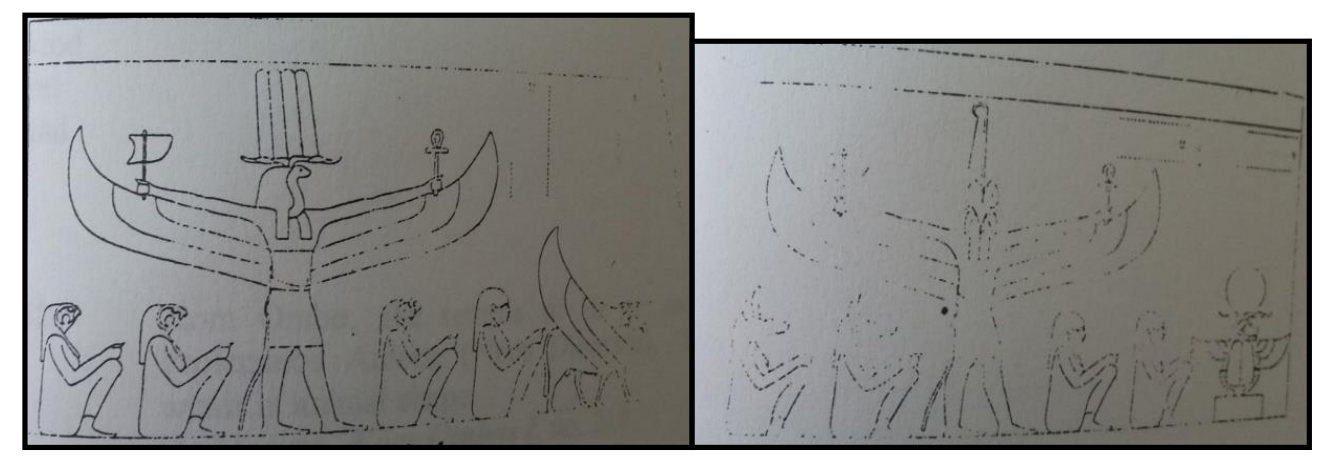

c. God of eastern wind d. God of western wind

Figure 4: a.b.c.d. Four gods of the wind, temple of Denderah, Græco-Roman Period After: El-Kasrawy, The Wind in the Ancient Egyptian Culture, fig. 124.

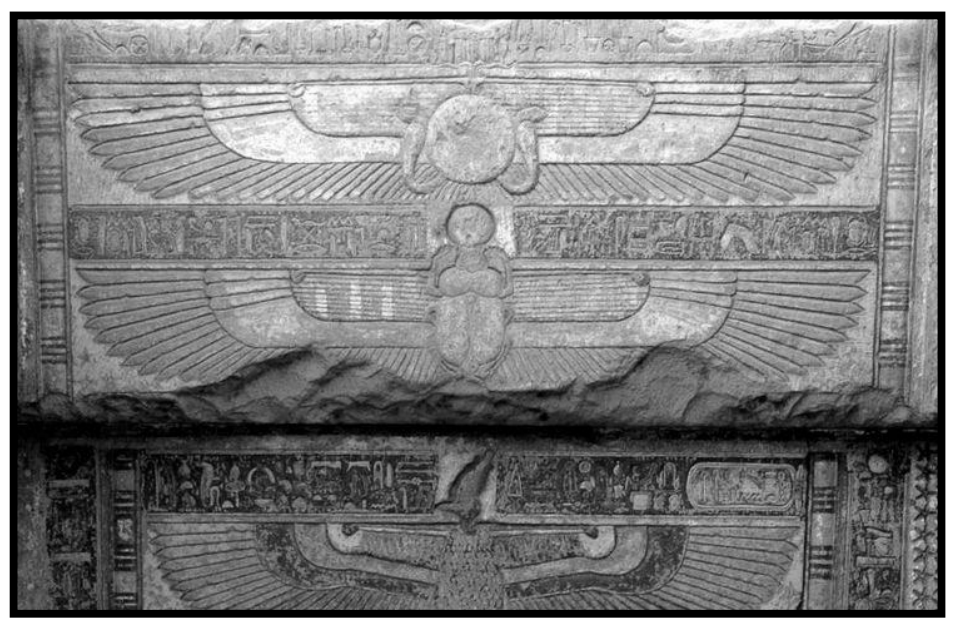

Figure 5: Osiris in the form of a winged scarab between the winged sun disc and the vulture, ceiling of the Osirian chapel, Dendera temple, Græco-Roman Period

After:

https://s-media-cacheak0.pinimg.com/736x/42/6b/36/426b36bf8b30b8252c0efb2f86c60014.jpg (accessed 28 $\underline{\text { March 2015, 3 AM) }}$ 


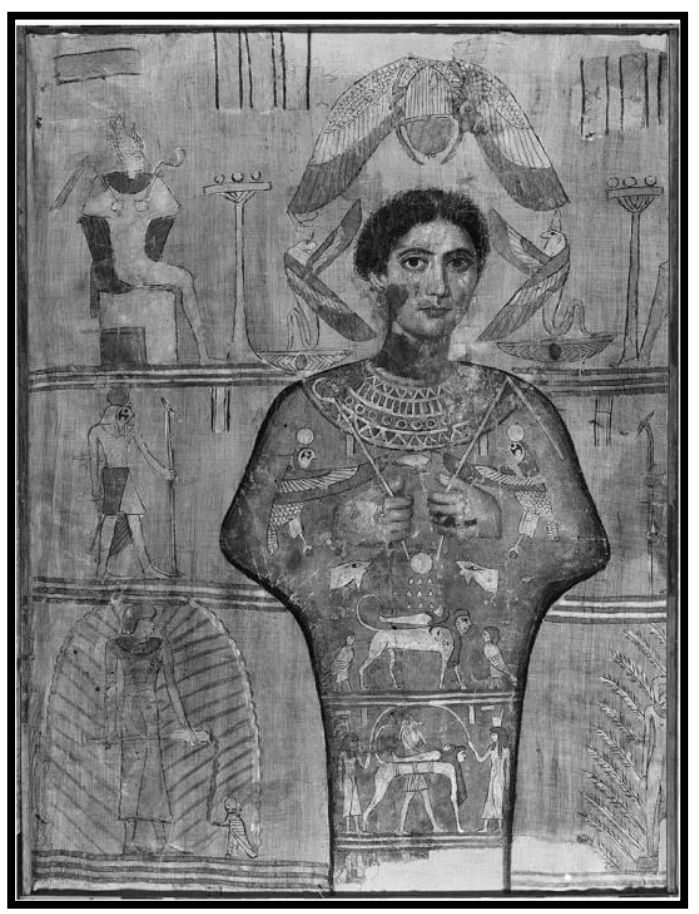

Figure 6: Osiris as a winged beetle surrounding the head of the deceased, linen shroud purchased at Akhmim, Mid to Late First century A.D., Museum of Fine Arts, Boston After: Riggs, The Beautiful Burial in Roman Egypt, 3, fig. 1.

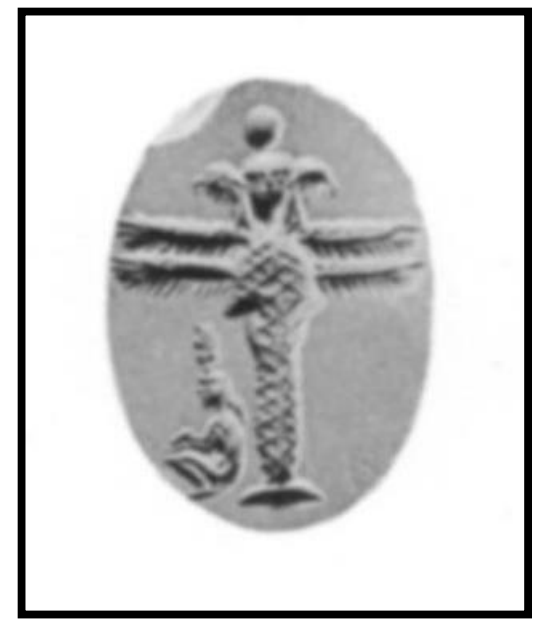

Figure 7: Magical stone depicting Osiris as a winged mummy, British Museum, London After: Bonner,“Amulets Chiefly in the British Museum”, pl. 96, no.2 


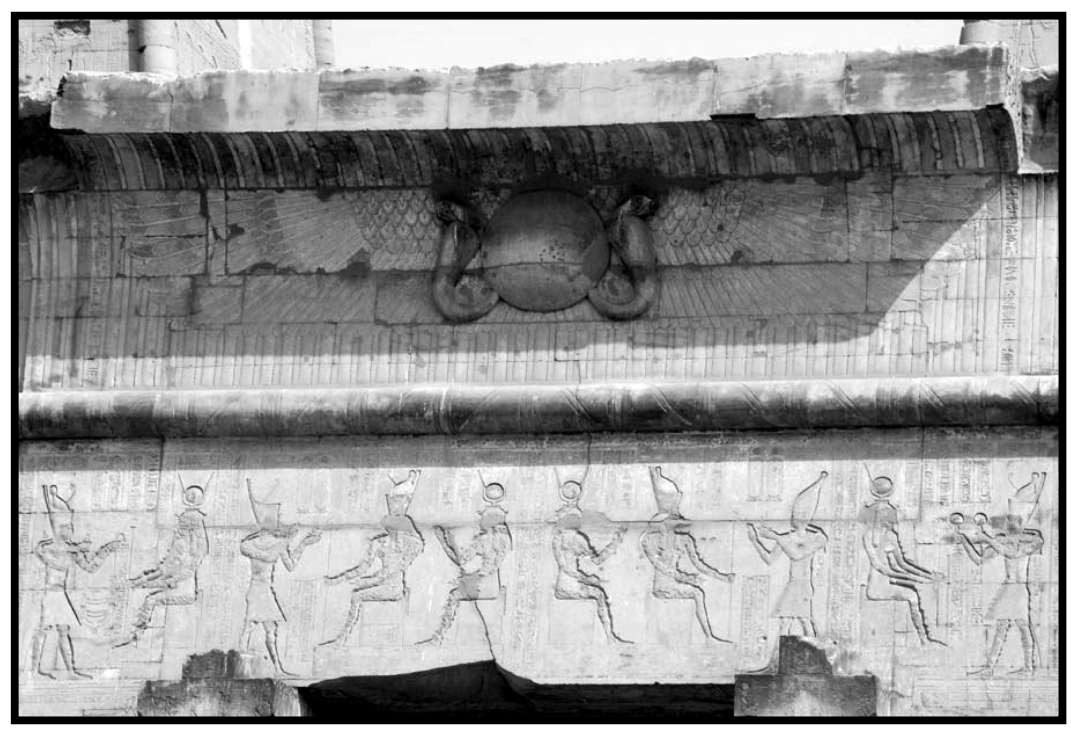

Figure 8: high relief depicting the winged sun disc of Horus Behdety above the gateway of the pylon ofEdfu temple, Græco-Roman Period

After: http://users.stlcc.edu/mfuller/edfu.html (accessed 18 October 2014, 2 AM)

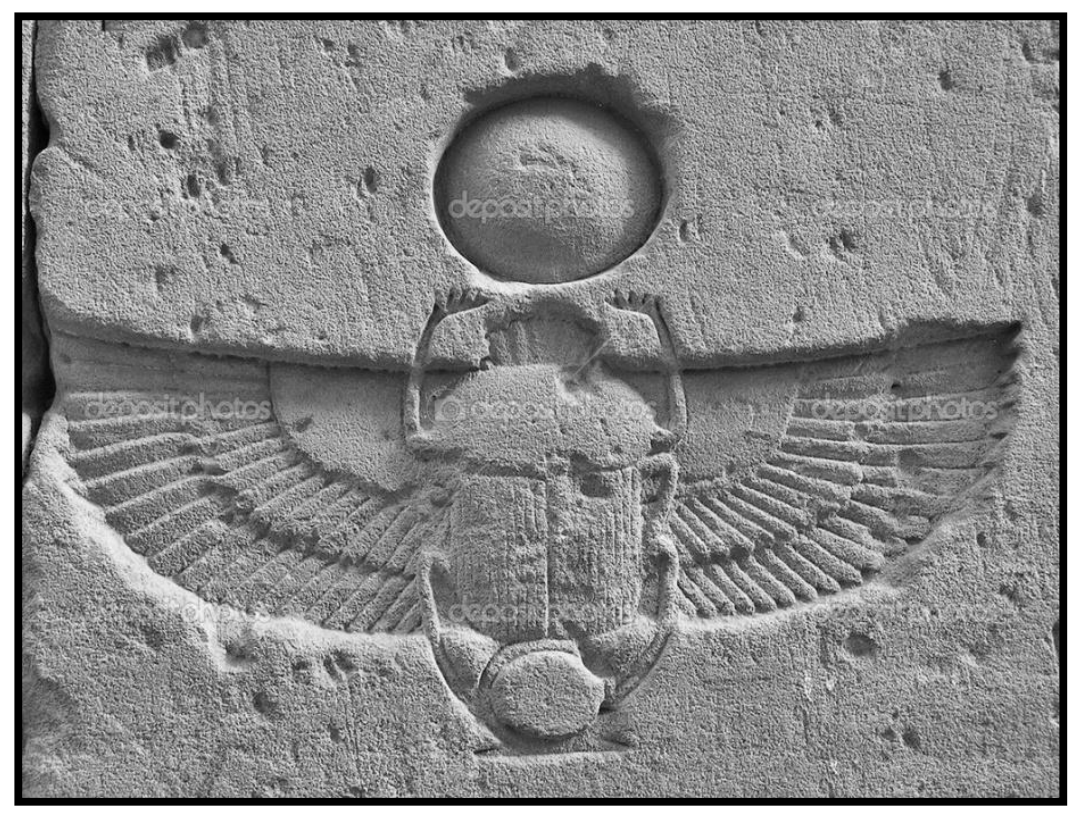

Figure 9: Relief of the winged beetle of Horus Bedety, Edfu temple, Græco-Roman Period

After: http://depositphotos.com/4623047/stock-photo-carved-scarab.html (accessed 13 January 2015, 13 PM) 


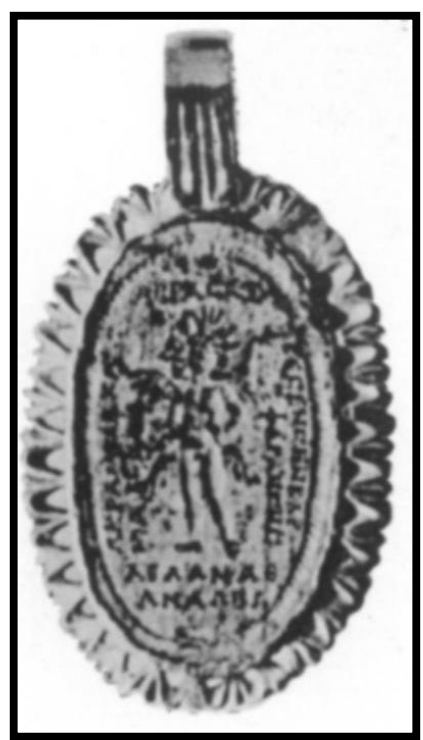

Figure 10: Magical stone depicting Harpokrates with four wings, British Museum, London

After: Bonner,“Amulets Chiefly in the British Museum”, pl. 100, no. 81.

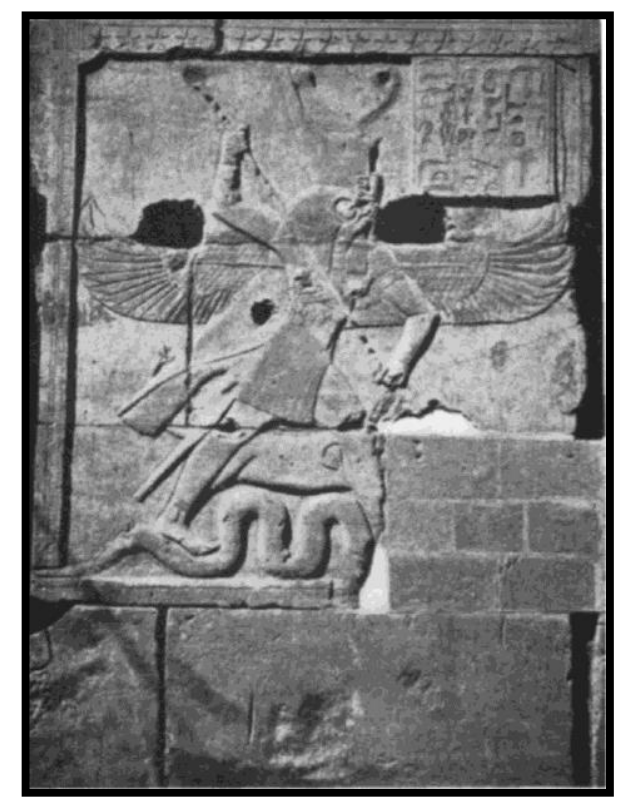

Figure 11: High relief representing Seth as a standing winged figure spearing Apophis snake, temple of Hibis, Kharga Oasis

After: TeVelde,Seth, God of Confusion, 20. 


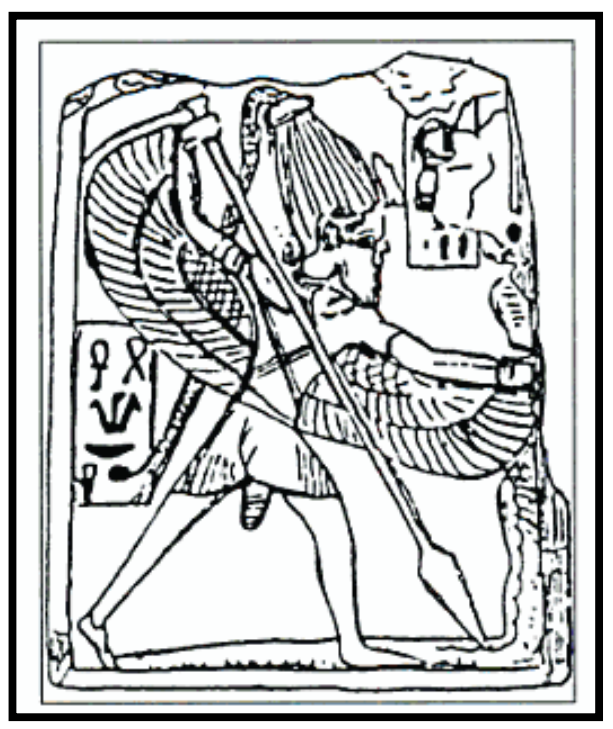

Figure 12: Fiancé plaque of Resheph assimilated with Seth as a winged figure spearing Apophis snake,Nineteenth-Twentieth Dynasties, Royal Art and History Museums, Brussels

After: Grande,“The Winged Reshep: Egyptian Iconographic Evidence”, 391, fig.1.

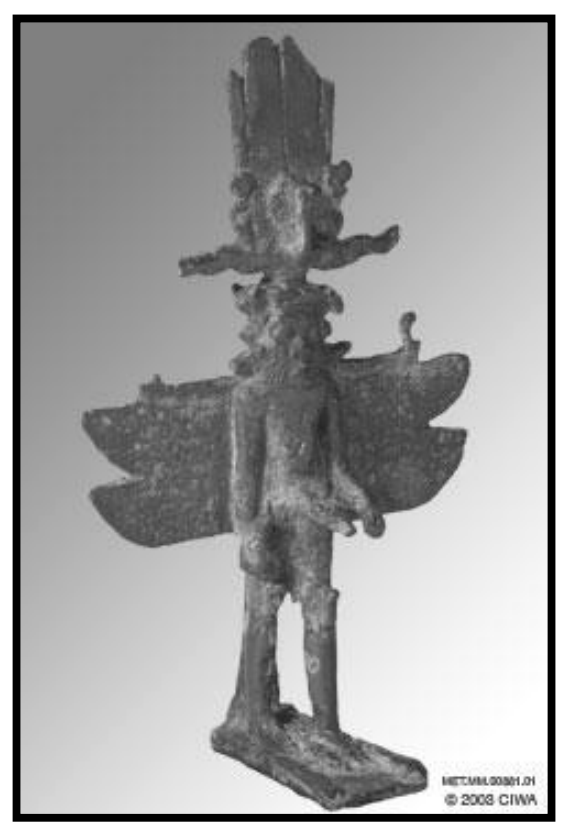

Figure 13: Bronze figurine representing Bes with four wings, Ptolemaic Period, Egyptian Museum, Cairo

After: http://www.virtual-egyptian-museum.org/Collection/FullVisit/Collection.FullVisitJFR.html?../Content/MET.MM.00881.html\&0(accessed 12 December 2014, 2 AM) 


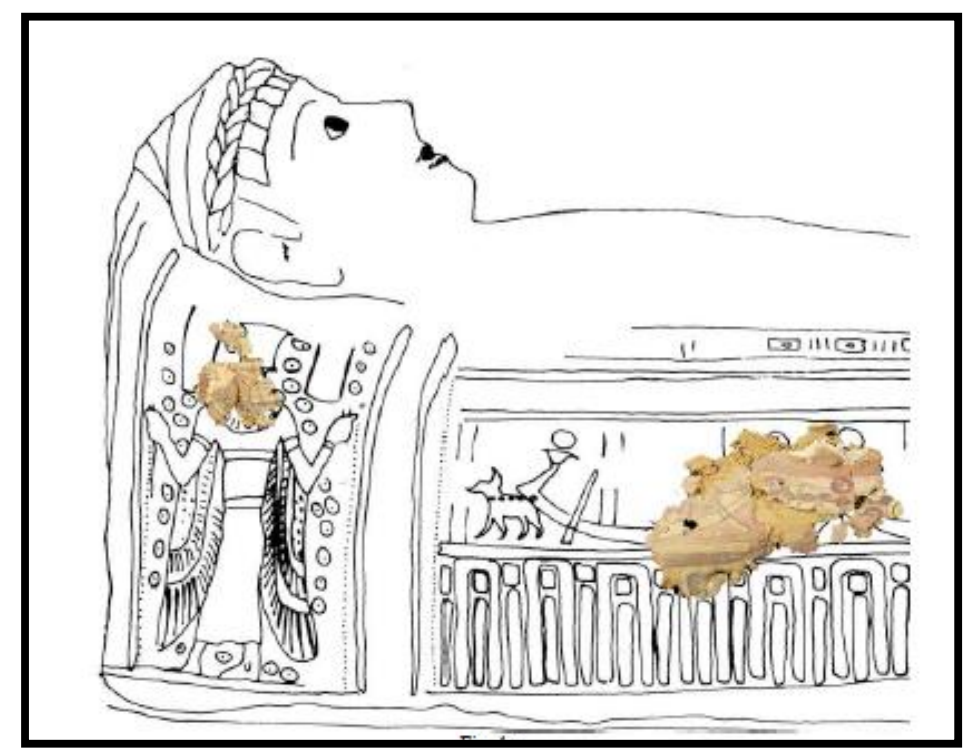

Figure 14: Coffin of Pinakht representing the winged Bes, discovered in Kharga Oasis, first half of the first century A.D., Ägyptisches Museum, 14291 (2), Berlin

After: Tallet,"Fragments d' El-Deir (oasis de Kharga) au tournant de notreère. A propos de Carl Schmidt et de William Hornblower", 403, fig.4a.

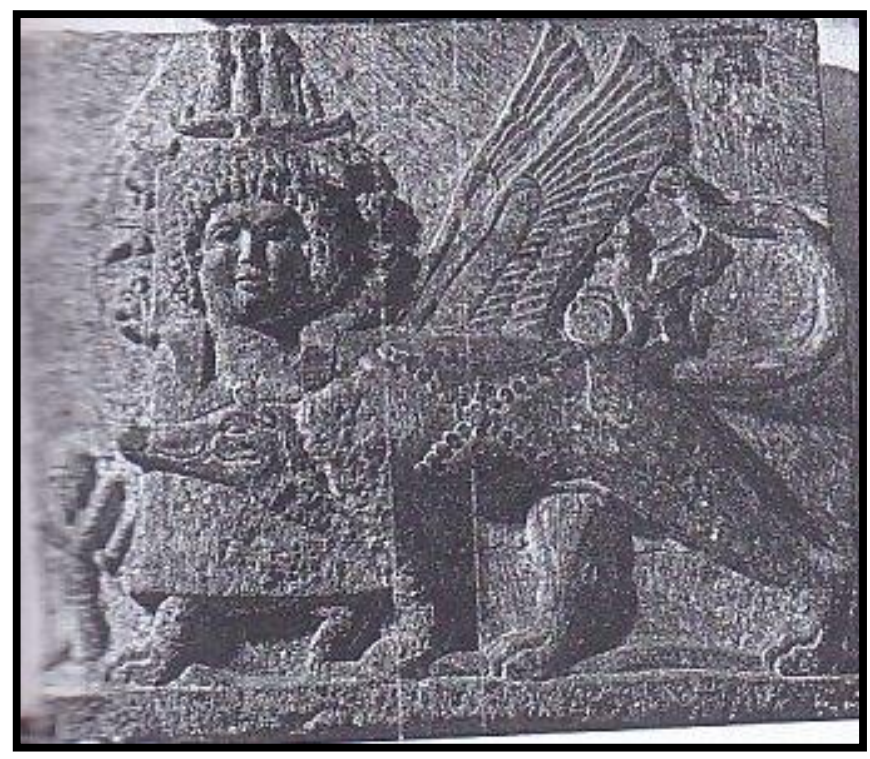

Figure 15: Limestone stela depicting god Tutu with outstretched winged in high relief, Roman Period, Egyptian Museum, Cairo After: Kaper, The Egyptian God Tutu, 295, S-1. 


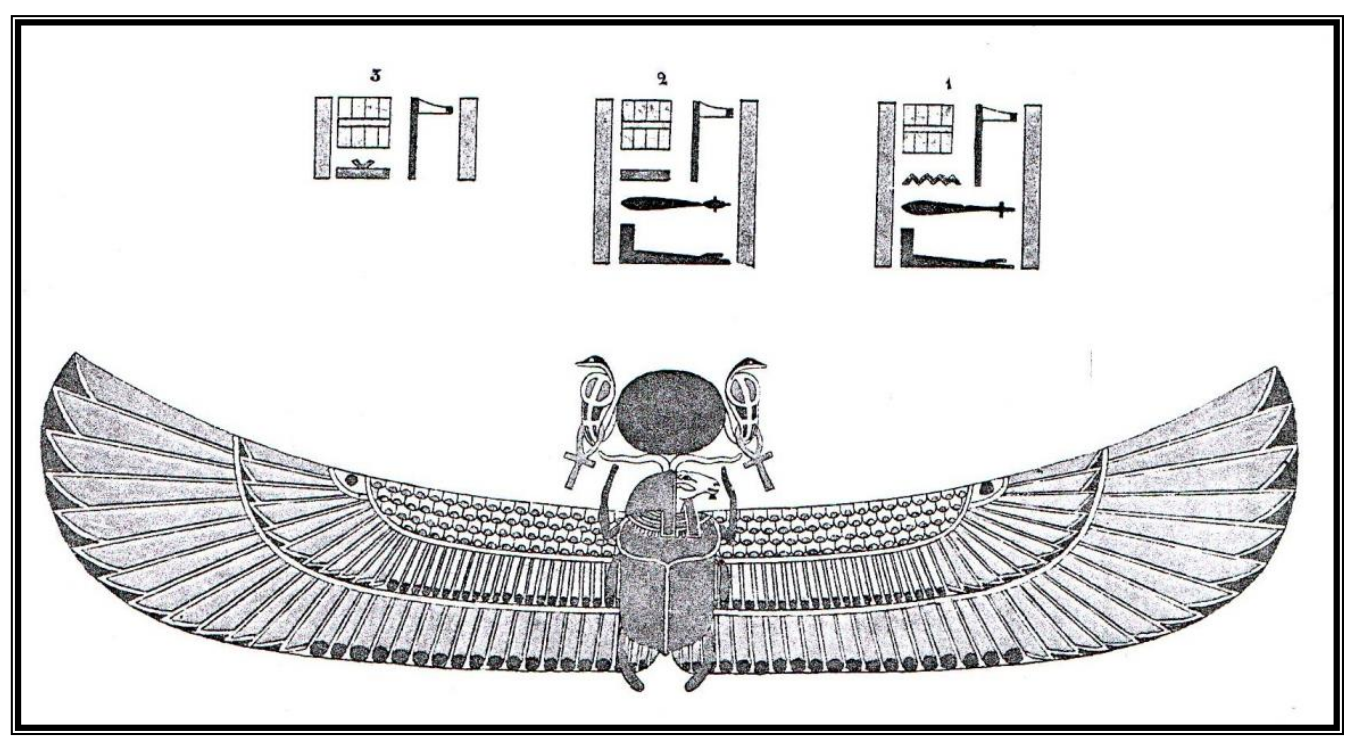

Figure16:Chnoubisas a ram headed scarab with outstretched wings

After: Champollion,Panthéonégyptien, 3, br.

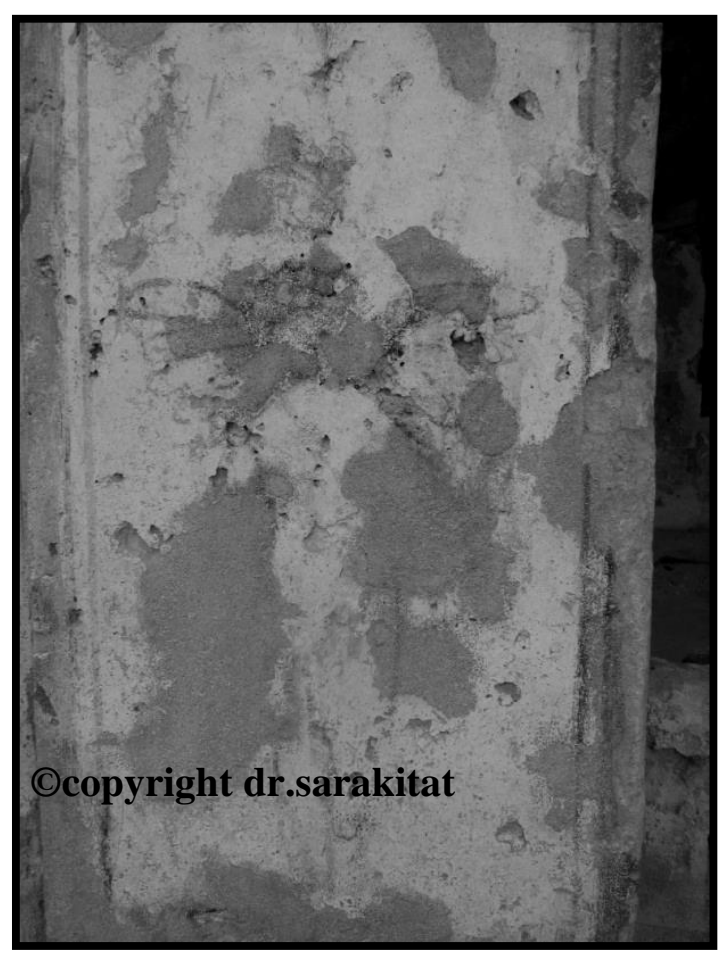


Figure 17: Painting of the winged Eros en face, Tomb of Stagni, Alexandria, Ptolemaic period

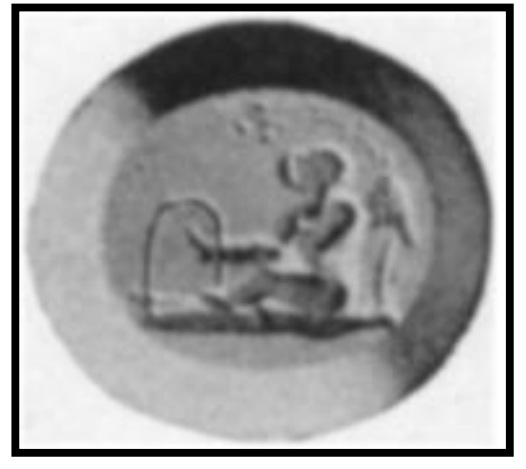

Figure 18: Magical gem depicting Eros with his wings in the seated position After: Bonner,“A Miscellany of Engraved Stones”, pl. 35, no.21.

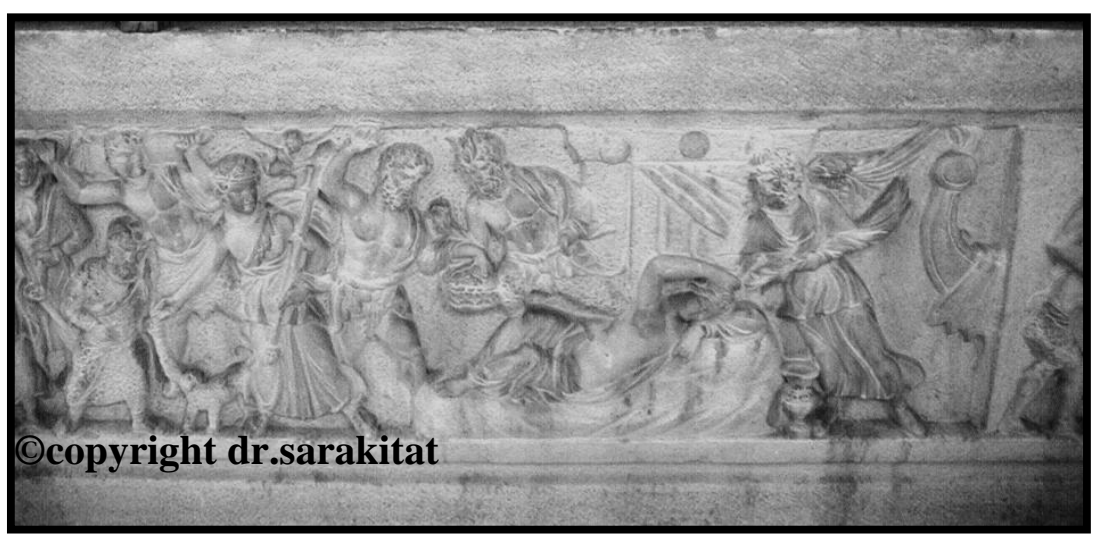

Figure 19: Marble Sarcophagus depicting the winged hypnos among the myth of Ariadne, Alexandria, Roman Period 


\section{References}

${ }^{(1)}$ David Frankfurter,Religion in Roman Egypt: Assimilation and Resistance (Princeton 1961), 4;Geraldine Pinch, Magic in Ancient Egypt, (London, 1994), 36.

(2)Pinch,Magic in Ancient Egypt, 36.

${ }^{(3)}$ Nora E. Scott, “The Metternich Stela”, BMMA 9, (1951), 204.

(4)Pinch, Magic in Ancient Egypt,119.

${ }^{(5)}$ Campbell Bonner, “Amulets Chiefly in the British Museum”, Hesperia 20,(1951), 318-319, no.17.

${ }^{(6)}$ Samar El-Kasrawy, The Wind in the Ancient Egyptian Culture; A Lingiustic -Cultural-Touristic Study, unpublished Ph. D. Diss., (Faculty of Tourism and Hotels, Alexandria University, 2004), 337, 341.

${ }^{(7)}$ El-Kasrawy,The Wind in the Ancient Egyptian Culture, 341; Richard H. Wilkinson,The Complete Gods and Goddesses of Ancient Egypt, (Cairo, 2005), 29; wind deities were also represented in the temple of KomOmbo with different details. For further details see; El-Kasrawy,The Wind in the Ancient Egyptian Culture, 343- 352.

${ }^{(8)}$ El-Kasrawy, The Wind in the Ancient Egyptian Culture, 341-342.

${ }^{(9)}$ Wilkinson, The Complete Gods and Goddesses of Ancient Egypt, 29.

( 10 'HeinrichBrugsch, Thesaurusinscriptionumaegyptiacarum: AltaegyptischeInschriften, gesammelt, verglichen, übertragenerklärt und autographiert, Abteilung HistorischbiographischeInschriftenaltaegyptischerDenkmaeler,(Leipzig, 1968), 847; El-Kasrawy, The Wind in the Ancient Egyptian Culture, 353, fig. 123b; Wilkinson, The Complete Gods and Goddesses of Ancient Egypt, 29.

${ }^{(11) B r u g s c h, ~ T h e s a u r u s i n s c r i p t i o n u m a e g y p t i a c a r u m, ~ 847 ; ~ E l-K a s r a w y, ~ T h e ~ W i n d ~ i n ~ t h e ~ A n c i e n t ~ E g y p t i a n ~ C u l t u r e, ~ 353, ~ f i g . ~}$ $123 b$

${ }^{(12)}$ MelangesAdolpheGutbub, “über die VierWinde in Ägypten”, StuttgarterBiblestudien, 84-85, (Stuttgart, 1977), 328353; Ahmed Fakhry, Denkmäler der OaseDachla, ArcheologischeVeröffentlichungen 28, (Zebern -Meinz, 1982), 60; Olaf E. Kaper, “The Astronomical Ceiling of Deir El Haggar in the Dakhla Oasis", JEA81, (1995), 186; El-Kasrawy,The Wind in the Ancient Egyptian Culture, 342-343, 356-357.

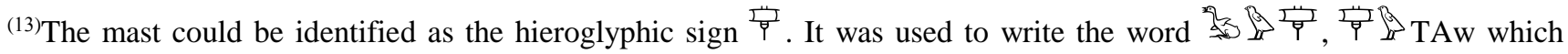
means "breath", "air", and "wind"; Raymond O. Faulkner, A Concise Dictionary of Middle Egyptian, (London, 1964), 303; Wb V, 350-351, no. a 1-10; Alan Gardiner, Egyptian Grammar; Being an Introduction to the Study of Hieroglyphs, $3^{\text {rd }}$ ed.,(Oxford, London, 1973), 499, no.5

${ }^{(14)}$ El-Kasrawy, The Wind in the Ancient Egyptian Culture, 342-343, 356, fig. 124; SylvieCauville, Dendara: Le temple d'Isis, (IFAO, 2009), 25.

${ }^{(15)}$ Cauville,Dendara, 25.

${ }^{(16)}$ Randy L.ShonkwilerThe Behdetite: A Study of Horus the Behdetite From the Old Kingdom to the Conquest of Alexander, A Dissertation submitted to the Faculty of the Division of the Humanities in Candidacy for the Degree of Doctor of Philosophy: Department of the Near Eastern Languages and Civilizations, The University of Chicago, ( Chicago, 2014), 84-85.

${ }^{(17)}$ SylvieCauville, S, Le temple de Dendara: Les chapellesosiriennes, vol. 1, Transcriptions et traductions, BiEtud117, (IFAO, 1997), 100, 140-141; ShonkwilerThe Behdetite,84-85.

${ }^{(18)}$ Christina Riggs,The Beautiful Burial in Roman Egypt; Art, Identity, and Funerary Religion, Oxford Studies in Ancient Culture and Representation, (Oxford, 2005), 3-4, 28, 103, 116, 147, 196, 224-225, 242; Shonkwiler,The Behdetite, p. 82

${ }^{(19)}$ Martin AndreasStadler, "Der Skarabäus alsosirianisches Symbol vornehmlichnachsäptzeitlichenQuellen", ZÄS128,( 2001), 71-83; Riggs, The Beautiful Burial in Roman Egypt, 3-4, 28.

${ }^{(20)}$ On the reverse, a scarabaeus is engraved with long inscription; Bonner "Amulets Chiefly in the British Museum", 23, no.2; Simone Michel, "Die MagischenGemmenimBritischen Museum", on the Campbell Bonner Magical Gems Database, 109, (2001), 109, no. 172 (http://www2.szepmuveszeti.hu/talismans/pandecta/301 accessed 10 May 2015).

${ }^{(21)}$ Veronica Ions, Egyptian Mythology, (London. 1988), 69; Shonkwiler, TheBehdetite, 1, 3, 6, 82.

${ }^{(22)}$ HermannKees, "Kultlegende und Urgeschichte: GrundsätzlicheBemerkungenzumHorusmythus von Edfu", $N G W G$, (Göttingen, 1930),345-350; Herbert Walter Fairman, "The Myth of Horus at Edfu I", JEA 21, issue 1, (1935), 27-36; Maurice Alliot, Le Culte d' Horus a Edfou au temps Ptolemees, vo.2, BiEtud20-1, (IFAO,1954), 441-445; WinfriedBarta, "Horus von Edfu", LÄ III, (Wiesbaden, 1980), 34- 35; Ions,Egyptian Mythology, 69. 
${ }^{(23)}$ Alan H. Gardiner, "Horus the Behdetite", JEA30, (1944), 46; Ions,Egyptian Mythology, 69; Claude Traunecker, The Gods of Egypt, ( Ithaca N.Y, 2001), 81-82; Shonkwiler,The Behdetite, 81-82.

${ }^{(24)}$ Fairman"The Myth of Horus at Edfu I", 27-35; Gardiner, "Horus the Behdetite",46; Barta, "Horus von Edfu", 34- 35; Shonkwiler, The Behdetite, 81-82.

${ }^{(25) B a r t a, ~ " H o r u s ~ v o n ~ E d f u ", ~ 34-~ 35 ; ~ M a x e n c e ~ d e R o c h e m o n t e i x, p u i s E ́ m i l e C h a s s i n a t ~, L e ~ t e m p l e ~ d e ~ E d f o u, ~ t o m e ~ I, ~}$ (IFAO,1984),112, 9-10; 157, 13-14; 412, 12; tome II, (IFAO,1984), 36, 11; Shonkwiler, The Behdetite, 152-153.

${ }^{(26)}$ Barta, "Horus von Edfu", 34- 35; Rochemonteix, puisChassinat,Le temple de Edfou, tome I, 112, 9-10; 283, 4-5; 412, 12; tome II, 36, 11.

${ }^{(27)}$ Barta, "Horus von Edfu", 34- 35; Rochemonteix,puisChassinat,Le temple de Edfou,tome I, 88, 9.

${ }^{(28)}$ Shonkwiler,TheBehdetite, 161.

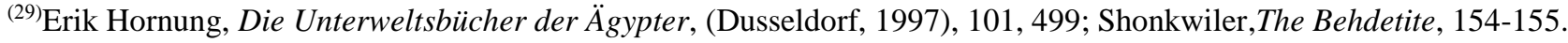

${ }^{(30)}$ Gardiner, "Horus the Behdetite", 47; Shonkwiler,TheBehdetite, 16.

${ }^{(31)}$ Barta, "Horus von Edfu", 34-35; Rochemonteix, puisChassinat,Le temple de Edfou, tome I, 146, 4.

${ }^{\left({ }^{32}\right)}$ Mesen is recognized to be a small town in Lower Egypt. However, it became also one of the names of Edfu beside Behdet; Pascal Vernus, "Mesen", LÄIV, (Wiesbaden, 1982), 108-109; Shonkwiler,The Behdetite, 83-84, 271, 304, 313.

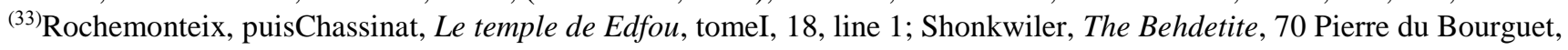
Le temple de Deir al-Médîna, MIFAO121, (IFAO, 2002), 53, 63, 65, 101;Shonkwiler,The Behdetite, 70-71.

(34) RaghildBjerreFinnestad, "Temples of the Ptolemaic and Roman Period; Ancient Traditions in New Contexts", in Byron Esely Shafer, and Dieter Arnold, Gerhard Haeny, Lanny Bell, and RaghildBjerreFinnestad (eds.), Temples of Ancient Egypt, $2^{\text {nd }}$ ed., (London, 2005), 207.

${ }^{(35)}$ Barta, "Horus von Edfu", 34- 35; Finnestad, "Temples of the Ptolemaic and Roman Period; Ancient Traditions in New Contexts",206; Shonkwiler,The Behdetite, 63, 122-123, 145-148.

${ }^{(36)}$ Shonkwiler,TheBehdetite, 16.

${ }^{(37)}$ Rochemonteix, puisChassinat, Le temple de Edfou,tomeI, 10, line 3 (montantdroit); Shonkwiler, The Behdetite, 145.

${ }^{(38)}$ Shonkwiler, The Behdetite, 145-146; Apy was also associated with Amun Re and god Khepri. The first textual appearance of Apy dates back to the First Persian period. This text was found in the temple of Hibis in Kharaga oasis. In this text, the winged beetle was used as a determinative for Apy which was described to be one of the souls of Amun. For further details see; Shonkwiler, The Behdetite, 145-150.

${ }^{(39)}$ Ions, Egyptian Mythology, 70; Shonkwiler, TheBehdetite, 148-149.

${ }^{(40)}$ Shonkwiler, The Behdetite, 148-149

${ }^{(41)}$ Rochemonteix, puisChassinat,Le temple de Edfou, tomeI, 11, lines 8, 12; Shonkwiler, The Behdetite, 148-149.

${ }^{(42)}$ Fairman, "The Myth of Horus at Edfu I", 36.

${ }^{\left.{ }^{43}\right)}$ Bonner "'Amulets Chiefly in the British Museum", 344, no.81.

${ }^{(44)}$ Bonner, "Amulets Chiefly in the British Museum", 333, no. 48; 344, no.81;ErgünLafl1, Maurizio Buora, and AttilioMastrocinque, "A New Osiriform Lamp from Antioch in the Hatay Archaeological Museum", Greek, Roman and Byzantine Studies 52, (2012),421-439 (http://www.academia.edu/7714305/A_New_Osiriform_Lamp_from_Antioch_in_the_Hatay_Archaeological_Museum accessed 9 May 201512 AM), 429;Anna Z. Zmorzanka, "Abrasax", Internet Version of the Universal Encyclopedia of Philosophy, (2015),(http://peenef2.republika.pl/angielski/hasla/a/abraxas.html accessed 10 May 201511 AM).On the reverse of this piece, Horus depicted crowned with the hemhem crown. His head is surrounded with a nimbus of twelve rays. For further details see; Bonner, " Amulets Chiefly in the British Museum”, 344, no.81

${ }^{(45)}$ Herman TeVelde, Seth, God of Confusion; A Study of his Role in Egyptian Mythology and Religion, (Leiden, 1977), 20, 29, 115; AlainBlottiére, Petit Dictionnaire des dieuxÉgyptiens, (Paris, 2000), 123; Maria J. LópezGrande,“The Winged Reshep: Egyptian Iconographic Evidence", in ZahiHawas, and Lyla Pinch Brock (eds.) Egyptology at the Dawn of the Twenty First Century; Proceedings of Tenth Eighth International Congress of Egyptologists 2000, volume 2: History, Religion, (Cairo, 2003), 389; Wilkinson,The Complete Gods and Goddesses of Ancient Egypt, 199.

${ }^{(46)}$ Grande,The Winged Reshep: Egyptian Iconographic Evidence", 389; Wilkinson, The Complete Gods and Goddesses of Ancient Egypt, 199.

${ }^{(47)}$ Frankfurter,Religion in Roman Egypt, 113; TeVeldeSeth, God of Confusion, 20, 29, 115; Blottiére, Petit Dictionnaire des dieuxÉgyptiens, 123; Wilkinson, The Complete Gods and Goddesses of Ancient Egypt, 199. 
${ }^{(48)}$ TeVelde, Seth, God of Confusion, 99-108; GriffithsInstitute (http://www.griffith.ox.ac.uk/gri/8ste450.pdf (accessed 18 November 2014, 11 AM), 26, no. 803-055-260).

${ }^{(49)}$ IzakCornelius, The Iconography of the Canaanite gods Reshef and Ba'al;Late Bronze and Iron Age I Periods (c 15001000 BCE), OBO 140, (Fribourg, 1994), 163- 164.

${ }^{(50)}$ Cornelius, The Iconography of the Canaanite gods Reshef and Ba'al, 163 -164; Nahum M. Sarna "The Mists of Time: Genesis I-II", in Ada Feyerick, Cyrus Herzl Gordon, Nahum M. Sarna (eds.), Genesis: World of Myths and Patriarchs,(New York, 1996), 76.

${ }^{(51)}$ Cornelius, The Iconography of the Canaanite gods Reshef and Ba'al, 162; for further examples see, Cornelius, The Iconography of the Canaanite gods Reshef and Ba'al,210-218.

${ }^{(52)}$ Cornelius rather believes that god Resheph was never depicted as a winged god; Grande, "The Winged Reshep: Egyptian Iconographic Evidence", 391-392.

${ }^{(53)}$ Grande, "The Winged Reshep: Egyptian Iconographic Evidence", 389-390, 394; Wilkinson,The Complete Gods and Goddesses of Ancient Egypt, 126-127.

${ }^{(54)}$ Grande, "The Winged Reshep: Egyptian Iconographic Evidence", 389-390, 394.

${ }^{\left({ }^{55}\right)}$ Grande, "The Winged Reshep: Egyptian Iconographic Evidence", 389, 391; Wilkinson, The Complete Gods and Goddesses of Ancient Egypt, 126-127.

${ }^{(56)}$ Wilkinson, The Complete Gods and Goddesses of Ancient Egypt, 126-127; Maciej M.Münnich, The God Reshep in the Ancient Near East, Orientalische Religion in der Antike 11, (Tübingen, 2013), 119-120.

${ }^{(57)}$ Grande, "The Winged Reshep: Egyptian Iconographic Evidence", 390-391.

${ }^{(58)}$ Alice Grenfell, "The Iconography of Bes, and of Phonetician Bes Hand Scarabs", PSBA 14, (1902), 24, 31; GeorgeMichalidis, "Le dieu Bes surunestèlemagique", BIE 42-43, (1960-62), 66; HartwigAltenmüller, "Bes", LÄ I, (Wiesbaden, 1975), 721; VeroniqueDasen, Dwarfs in Ancient Egypt and Greece, (Oxford, 1993), 64-65; Wilkinson, The Complete Gods and Goddesses of Ancient Egypt, 103.

${ }^{(59)}$ Grenfell , "The Iconography of Bes, and of Phonetician Bes Hand Scarabs", 22; James F. Romano, "The Origin of the Bes-image", BES 2, (1980), 40; Dasen,Dwarfs in Ancient Egypt and Greece, 60.

${ }^{(60)}$ Altenmüller, "Bes", 721-722.

${ }^{\left({ }^{61}\right)}$ Frankfurter, Religion in Roman Egypt, 49; for further examples see; GeorgesDaressy, Textes et dessinsmagiques; Catalogue general des antiquiteségyptiennes du Musée du Caire, nos. 9401-9449,(IFAO, 1903), nos. 9428-9429.

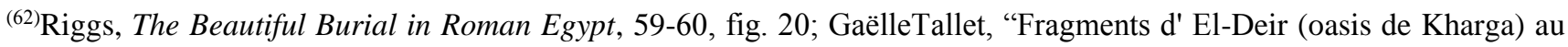
tournant de notreère. A propos de Carl Schmidt et de William Hornblower", dansGaëlleTallet et ChristianeZivie-Coche (eds.), Le myrte et la rose, (Montpellier, 2014), 386-387.

${ }^{(63)}$ Dasen, Dwarfs in Ancient Egypt and Greece, 66-67; Tallet"Fragments d' El-Deir (oasis de Kharga) au tournant de notreère. A propos de Carl Schmidt et de William Hornblower", 386-387.

${ }^{(64)}$ Tallet, "Fragments d' El-Deir (oasis de Kharga) au tournant de notreère. A propos de Carl Schmidt et de William Hornblower", 387.

${ }^{(65)}$ Pinch, Magic in Ancient Egypt, 36; Olaf E. Kaper, The Egyptian God Tutu; A Study of the Sphinx-God and Master of Demons with a Corpus of Monuments, OLA 119, (Leuven, 2003), 41; Wilkinson, The Complete Gods and Goddesses of Ancient Egypt, 183.

${ }^{(66)}$ Kaper, The Egyptian God Tutu, 41, 81-82; Penelope Wilson, A Ptolemaic Lexikon: A Lexicographical Study of the Texts in the Temple of Edfu, OLA 78,(Leuven, 1997, 705.

${ }^{(67)}$ Kaper, The Egyptian God Tutu, 55.

${ }^{(68)}$ Kaper, The Egyptian God Tutu, 81-82.

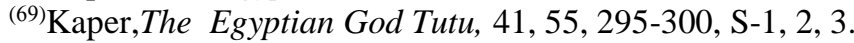

${ }^{(70)}$ Kaper,The Egyptian God Tutu, 295-297, S-1.

${ }^{(71)}$ Jean FrançoisChampollion, Panthéonégyptien: Collection des personnagesmythologiques de l'ancienneÉgypte, d'après les monuments,(Paris, 1992),3 ter. 
${ }^{(72)}$ Alexander S.Murray, Who's Who in Mythology; Classic Guide to the Ancient World, (London, 1988), 168-172; Robin Hard, The Routledge Handbook of Greek Mythology: Based on H.J. Rose's "Handbook of Greek Mythology", (London, 2004), 23; Luke Roman, and Monica Roman, Encyclopedia of Greek and Roman Mythology, (New York, 2010), 158; Radcliffe G. Edmonds III, "Orphic Mythology", in Ken Dowden and Niall Livingstone (eds.), A Companion to Greek Mythology, (Oxford, 2011), 78-79.

${ }^{(73)}$ Hard, The Routledge Handbook of Greek Mythology, 23;L. Roman, and M. Roman, Encyclopedia of Greek and Roman Mythology, 158; Edmonds, “Orphic Mythology”, 78-79.

${ }^{(74)}$ L. Roman, and M. Roman, Encyclopedia of Greek and Roman Mythology, 158; Edmonds, "Orphic Mythology", 78-79.

${ }^{(75)}$ DiskinClay, "Plato Philomythos", inRoger D. Woodard (ed.), The Cambridge Companion to Greek Mythology, (New York, 2007), 210-236, 232.

${ }^{(76)}$ Murray,Who's Who in Mythology, 168-172; L. Roman, and M. Roman, Encyclopedia of Greek and Roman Mythology, 159.

${ }^{(77)}$ Murray Who's Who in Mythology, 168-172; Hard, The Routledge Handbook of Greek Mythology, 23;L. Roman, and M. Roman Encyclopedia of Greek and Roman Mythology, 158-159.

(78) Marjorie SusaVenit, Monumental Tombs of Ancient Alexandria, (Cairo, 2002), 161-163.

${ }^{(79)}$ Campbell Bonner, “A Miscellany of Engraved Stones", Hesperia 23, issue 2, (1954), 144, no. 21.

${ }^{\left({ }^{80}\right)}$ Murray, Who's Who in Mythology,194; Mirriam-Webster's Encyclopaedia of Literature; A Comprehensive and Authoritative Guide to the World of Literature Authors, Works, Terms, and topics from all ears and all parts of the World, (Washington, 1995), 574; Hard, The Routledge Handbook of Greek Mythology, 29-30; L. Roman, and M. Roman, Encyclopedia of Greek and Roman Mythology, 246.

${ }^{(81)}$ Murray, Who's Who in Mythology, 194.

${ }^{(82)}$ L. Roman, and M. Roman,Encyclopedia of Greek and Roman Mythology, 246.

${ }^{(83)}$ Murray, Who's Who in Mythology, 194.

(84) Hard, The Routledge Handbook of Greek Mythology, 30; Mirriam-Webster's Encyclopedia of Literature , 574; L. Roman, and M. Roman, Encyclopedia of Greek and Roman Mythology, 246; the cave of Hypnos was described not to see the sun light. Number of poppies and hypnotic plants were at the entrance of his cave which had no door gates. The river of forgetfulness, namely the stream of Lethe, flowed into his cave. For further details see; Hard, The Routledge Handbook of Greek Mythology, 30.

${ }^{\left({ }^{85}\right)}$ Hard, The Routledge Handbook of Greek Mythology, 30.

${ }^{(86)}$ Murray, Who's Who in Mythology, 194.

${ }^{\left({ }^{87}\right.}$ Evaristo Breccia, Alexandria Ad Aegyptum: A Guide to The Ancient and Modern Town, and to its Graeco-Roman Museum, (Bergamo, 1922), 235-237.

${ }^{(88)}$ The winged sun disc was regarded by Goedicke to be a symbol of the separation of this world and that of the gods, or the representation of both the existing world and the overweening world; Hans Goedicke, "Unity and Diversity in the Oldest Religion of Ancient Egypt", in Hans Goedicke, H and Jimmy Jack McBee Roberts (eds.), Unity and Diversity: Essays in the History, Literature, and Religion of the Ancient Near East, (Baltimore, 1975), 205-206. 